\title{
Measuring good governance for complex ecosystems: Perceptions of coral reef- dependent communities in the Caribbean
}

\author{
Turner RA ${ }^{a^{*}}$, Fitzsimmons $C^{b}$, Forster $\mathrm{J}^{\mathrm{b}}$, Mahon $\mathrm{R}^{\mathrm{a}}$, Peterson $\mathrm{A}^{\mathrm{a}}$, Stead SM ${ }^{\mathrm{b}}$ \\ ${ }^{a}$ Centre for Resource Management and Environmental Studies (CERMES), University of the West Indies, Cave Hill Campus, Barbados, BB11000 \\ ${ }^{b}$ School of Marine Science and Technology, Newcastle University, Newcastle upon Tyne, UK, NE1 TRU \\ *Corresponding author. r.turner@exeter.ac.uk
}

\begin{abstract}
Good governance is widely seen as a prerequisite for effective natural resources management in the context of environmental decline and increasing anthropogenic pressures. Few studies quantitatively examine governance principles, or explore links between perceptions of community members and the governance that shapes their behaviour. Comparative work, spanning multiple sites and contexts, is rare. This paper measures community members' perceptions of governance in twelve coral reef-dependent communities across four countries in the Wider Caribbean Region. In relation to established principles of 'good governance', multiple correspondence analysis indicates that perceptions can be reliably described using two themes, institutional acceptance and engagement. These explain over $50 \%$ of variation in individual perceptions. These measurable themes provide an indication of the social fit of governance arrangements, and have implications for expected outcomes, including support for management and compliance with regulations. Cluster analysis provides unique empirical evidence linking structural characteristics of governance to community perceptions; four of five good governance indicators were present in communities with positive perceptions. Results suggest a combination of supportive structures and processes are necessary to achieve governance systems positively perceived by community members. Findings are relevant to those seeking to design management systems and governance structures that are appropriate to local circumstances and will engender stakeholder support.
\end{abstract}

Keywords: Good governance; coral reefs; community perceptions; institutional acceptance; engagement

\section{Introduction}

Globally, increasing pressures on natural resources present management challenges, particularly for complex and dynamic socialecological systems. Many symptoms of environmental decline have been ultimately attributed to poor governance. This has failed to limit anthropogenic impacts and constrained effective management (Hughes et al., 2010; Mora et al., 2009). With environmental pressures exacerbated by the threat of climate change, there is demand for improved governance solutions (Cash et al., 2006). Governance is defined here as the structures and processes that determine how decisions are made, power is exercised and responsibilities allocated (Graham et al., 2003). Contemporary thinking recognises resource governance as broader than government, involving both formal and informal processes (Mahon et al., 2009). Governance not only comprises rules and regulations; it also includes interactions among many actors in society beyond government, including civil society and the private sector (Kooiman et al., 2005).

Governance 'quality' can be measured against articulated standards of 'good governance'. This is important if areas for improvement are to be identified (Chuenpagdee, 2011). To date, effectiveness has commonly only been inferred via measurement of ecological, social, or economic outcomes under particular governance arrangements (Cinner et al., 2012a; Evans et al., 2011; Gutiérrez et al., 2011). However, there are compelling reasons to assess governance process as well as outcomes, as these are expected to improve the quality of decision-making and implementation (Mahon et al., 2009, Rauschmayer et al., 2009). A range of procedural principles expected to support more effective management have been proposed (Armitage et al., 2007; Biermann, 2007; Graham et al., 2003; Kooiman et al., 2005; Lockwood, 2010; Ostrom, 1990), and empirical studies have shown how particular governance principles influence outcomes of resource management (e.g. transparency, Mora et al. 2009; participation, Persha et al. 2011). Developments in the fields of common pool resource governance, co-management and institutional analysis have also contributed to an understanding of the structural characteristics of governance systems likely to facilitate or inhibit the application of good governance principles (Agrawal, 2001; Anderies et al., 2004; Armitage et al., 2007; Fanning et al., 2013; Imperial and Yandle, 2005; Ostrom, 1990). 
Despite increasing interest in natural resource governance, few studies assess how those being governed perceive the application of governance principles. These perceptions are important, as governance success relies to a high degree on the perceived fit and acceptance of institutions by resource users and the public (DeCaro and Stokes, 2013). Community perceptions of governance and management arrangements can influence resource use behaviour (Gelcich et al., 2008, 2005; McClanahan et al., 2005; Warner and Pomeroy, 2012). Perceptions have potential implications for willingness to engage in decision-making, levels of support for management, and compliance with regulations (Mora et al., 2009; Raakjær Nielsen and Mathiesen, 2003). Measuring perceptions can indicate the degree to which governance systems are endorsed by community members (DeCaro and Stokes, 2013). A number of studies explore community perceptions of particular governance principles (e.g. participation or legitimacy) and their implications for resource management (Dalton et al., 2012; Pita et al., 2010; Raakjær Nielsen and Mathiesen, 2003). However, no studies to date have examined community members' perceptions in relation to a wide range of procedural principles. Furthermore, none have explored links between these perceptions and structural arrangements across multiple sites and social-ecological contexts. Such studies are needed to further understand the role of governance structures and processes in shaping relationships between governing systems and those governed.

While methods for evaluating the health of ecological, social or economic systems are relatively well established, on-going monitoring of governance structures and processes is comparatively rare, inhibiting proactive improvement (Dale et al., 2013; Plummer and Armitage, 2007). Qualitative research remains essential to the understanding of complex governance systems, but quantitative indicators of governance quality can support monitoring and aid diagnosis of governance weaknesses (Kaufmann et al., 2000). Previous studies largely comprise either comparative assessments at national scale, which may mask local differences, or detailed case studies, which make generalisation difficult (Engle and Lemos, 2010). Recent work suggests that context is critical, requiring examination of combinations of variables associated with positive or negative outcomes (Armitage et al., 2007; Basurto et al., 2013). This paper seeks to capture both local and national differences. By studying three communities within each of four countries in the Wider Caribbean Region, we explore differences within and between countries in a diverse region, highlighting important implications for coral reef managers. This knowledge can help design institutions appropriate to both the environmental problems to be addressed and the local circumstances (DeCaro and Stokes, 2013; Ostrom, 2007).

The aim of this study is to measure community perceptions of good governance principles and assess their relationship to governance structures in twelve coral reef-dependent sites across four countries. The specific objectives were to: 1) assess perceptions of reef governance in relation to established 'good governance' principles; 2) identify any underlying themes driving differences in perceptions of principles; and 3) characterise governance structures associated with different perceptions.

\subsection{Conceptual framework}

A wide variety of frameworks informing the design of natural resource governance arrangements have been proposed. These fall into three broad categories. First, 'substantial' principles such as efficiency, equity, and sustainability direct the development of governance goals and outcomes (Agrawal, 2001; Bavinck and Chuenpagdee, 2005; Mahon et al., 2005, Ostrom 2007). Second, procedural principles encompass the rules, norms and values that guide decision-making processes (Bavinck et al., 2005). Third, a number of frameworks provide recommendations for structural characteristics of institutional arrangements (Agrawal, 2001; Fanning et al., 2007; Ostrom, 1990; Pomeroy, 2007). The latter two are the focus of this paper, which explores perceptions of procedural principles (hereafter 'principles'), and the structural characteristics that may facilitate their implementation. Relevant developments in governance theory are reviewed in the following sections, and concepts underpinning the metrics used in this study are discussed.

\subsubsection{Procedural principles}

Effective governance is ultimately judged on environmental and social outcomes, but the considerable time lag between governance processes and their outcomes means 'good governance' indicators are required in the early stages. Though the correspondence between good governance and good outcomes is an active area of research, this relationship is complex and remains largely undefined. Good governance principles provide a normative basis to guide the processes through which governance goals are developed and achieved (Kooiman et al., 2005; Lockwood, 2010). In doing so, they provide a 'conceptual yardstick' against which to evaluate the quality of governance (Kooiman et al., 2005). The application of these principles is expected to lead to improved management of marine resources. Procedural principles are particularly critical to contemporary theories of governance, which focus on interactions and processes rather than prescribing goals (Kooiman et al. 2005, Ostrom 2007). Principles set standards for how interactions among components of the governance system, i.e. within and between the 'governing system' and the social 'system-to-be-governed', are undertaken. Measurement of their application in different governance systems must therefore consider the perspective of those being governed. 
Research has increasingly examined good governance principles, both in general (e.g. Kaufmann 2010), and specifically in relation to natural resources management and protected areas (Graham et al. 2003; Kooiman et al. 2005; Jentoft et al. 2007; Biermann et al. 2010; Lockwood 2010; Lockwood et al. 2012). Such principles are thought to be relevant across the broad range of circumstances and diverse governance arrangements under which natural resources are managed (Graham et al., 2003). This study draws on seven principles of good governance outlined specifically in relation to natural resources management: legitimacy, transparency, accountability, inclusiveness, fairness, connectivity and resilience (Lockwood, 2010; Table 1). This framework is based on literature review, expert panel exercises and field trials, thus it shares common principles with many other governance frameworks (e.g. Armitage et al., 2007; Biermann, 2007; Graham et al., 2003; Kooiman et al., 2005). For each principle, Lockwood (2010) proposes a series of corresponding 'performance outcomes' that can be used to identify good governance. In this study we consider one performance outcome for each principle (Table 1), selecting those likely to be observable and easily understood by community members.

Table 1. Description of governance principles and performance outcomes measured, based on Lockwood (2010), and interview questions relating to each governance principle

\begin{tabular}{|c|c|c|}
\hline $\begin{array}{l}\text { Governance } \\
\text { principle }\end{array}$ & Performance outcome measured & Interview question \\
\hline Legitimacy & Governors act with integrity and commitment & $\begin{array}{l}\text { Do you think the people that look after coral reefs } \\
\text { in this area do a good job? }\end{array}$ \\
\hline Transparency & The reasoning behind decisions is evident & $\begin{array}{l}\text { When they make decisions, is information provided } \\
\text { to you and the rest of the community? }\end{array}$ \\
\hline Accountability & The governing body is answerable to its constituency & $\begin{array}{l}\text { Are there ways you can challenge the rules made } \\
\text { about reefs? }\end{array}$ \\
\hline Inclusiveness & $\begin{array}{l}\text { All stakeholders have appropriate opportunities to } \\
\text { participate in the governing body's processes and } \\
\text { actions }\end{array}$ & $\begin{array}{l}\text { Do you have an opportunity to participate in } \\
\text { decisions made about reefs? }\end{array}$ \\
\hline Fairness & Decisions are made consistently and without bias & $\begin{array}{l}\text { When people enforce the rules, is everybody } \\
\text { treated fairly? }\end{array}$ \\
\hline Connectivity & $\begin{array}{l}\text { The governing body is effectively connected with } \\
\text { governing bodies operating at the same governance } \\
\text { level }\end{array}$ & $\begin{array}{l}\text { Do different groups that have an interest in coral } \\
\text { reefs work well together? }\end{array}$ \\
\hline Resilience & $\begin{array}{l}\text { The governing body has procedures to identify, assess } \\
\text { and manage risk }\end{array}$ & $\begin{array}{l}\text { Do the people in charge of reefs have plans in place } \\
\text { to respond to emergencies or future changes? }\end{array}$ \\
\hline
\end{tabular}

\subsubsection{Structural characteristics}

In recent decades, efforts to identify governance structures that support sustainable, adaptive management of marine ecosystems have intensified (Agrawal, 2001; Anderies et al., 2004; Armitage et al., 2007; Fanning et al., 2013; Imperial and Yandle, 2005; Ostrom, 1990). Conventional approaches are perceived as having failed to manage common pool resources sustainably, neglecting to account for uncertainty, address issues of equity, and engender support of stakeholders (Costanza, 1998; Gutiérrez et al., 2011; Ostrom, 2007). In response, hierarchical modes of governance, in which resources are managed primarily through formal institutions established by nation states, have moved towards more inclusive approaches. These emphasise devolution or decentralisation of management, participation of stakeholders, and wider distribution of decision-making power (Armitage et al., 2007; Folke et al., 2005; Lockwood, 2010). Co-management approaches, in which power and responsibility are shared between government and local stakeholders, have been central to this trend (Berkes, 2007).

Empirical studies have examined the extent to which governance arrangements reflect guidance for effective institutional design, and the implications for governance outcomes (e.g. Cinner et al., 2012b; Cinner et al., 2012a; Gelcich et al., 2006). However, few studies have quantitatively examined the role of governance structures in facilitating the implementation of 'good governance' principles. We address this by exploring relationships between governance structures and community members' perceptions of principles among study sites. Research investigating characteristics conducive to the establishment and maintenance of sustainable institutions has moved towards a diagnostic approach, seeking to understand successful combinations of structural and contextual factors (Basurto, 2013; Ostrom, 2009, 2007). Though this study was not designed based on Ostrom's (2007) diagnostic framework for analysis of social-ecological systems, we contribute to operationalising part of the framework corresponding to five key characteristics of the governance system (GS) (Table 2), while the governance principles discussed (section 1.1.1) are relevant to the 
interactions (I) component of the framework. Selection of indicators was based on a review of relevant literature and provides a point of departure for comparison across study location.

Table 2. Description of structural characteristics of coral reef governance arrangements assessed in each community, with supporting references for inclusion of each metric. Indicators are organised to correspond with components of the governance system (GS) outlined in Ostrom's diagnostic framework for analysis of social-ecological systems (Ostrom, 2007, 2009)

\begin{tabular}{|c|c|c|c|}
\hline $\begin{array}{l}\text { Governance system } \\
\text { (GS) component }\end{array}$ & Indicator & Description & References \\
\hline $\begin{array}{l}\text { GS1 Government } \\
\text { organisations }\end{array}$ & $\begin{array}{l}\text { Local government } \\
\text { organisation }\end{array}$ & $\begin{array}{l}\text { Presence of a devolved government organisation involved in coral } \\
\text { reef management in the community }\end{array}$ & (Pomeroy, 2007) \\
\hline \multirow[t]{2}{*}{$\begin{array}{l}\text { GS2 } \\
\text { Nongovernment } \\
\text { organisations }\end{array}$} & 1) Active local NGO & $\begin{array}{l}\text { Presence of an NGO engaged in coral reef management in the } \\
\text { community }\end{array}$ & $\begin{array}{l}\text { (Folke et al., } \\
\text { 2005; Pomeroy, } \\
\text { 2007) }\end{array}$ \\
\hline & $\begin{array}{l}\text { 2) Resource user } \\
\text { organisation }\end{array}$ & Presence of resource user organisations at community level & (Pomeroy, 2007) \\
\hline
\end{tabular}

\begin{tabular}{lll}
$\begin{array}{l}\text { GS3 Network } \\
\text { structure }\end{array}$ & $\begin{array}{l}\text { Access to } \\
\text { information from } \\
\text { reef management } \\
\text { network }\end{array}$ & $\begin{array}{l}\text { Degree of access to information from a broader network of actors } \\
\text { involved in reef management, measured based on reported } \\
\text { information-sharing relationships between community-level actors } \\
\text { and other organisations or departments }\end{array} \quad \begin{array}{l}\text { (Bodin et al., } \\
\text { and Rova, 2010) }\end{array}$ \\
$\begin{array}{l}\text { GS7 Constitutional } \\
\text { rules }\end{array}$ & $\begin{array}{l}\text { Level of co- } \\
\text { management }\end{array}$ & $\begin{array}{l}\text { Typology of categories representing a range of stakeholder } \\
\text { involvement in decision-making: } 1 \text { ) consultative - government } \\
\text { interacts with stakeholders but often makes decisions; } 2) \\
\text { collaborative - government and stakeholders jointly make } \\
\text { decisions; } 3) \text { delegated - government lets formally organised } \\
\text { stakeholders make decisions }\end{array}$ \\
\hline
\end{tabular}

\section{Background and study sites}

\subsection{Marine resource governance in the Caribbean}

Coral reefs provide a relevant context for investigating governance quality as their exceptionally high biodiversity occurs in nearshore environments accessible to large coastal populations (Hoegh-Guldberg et al., 2007). As common pool resources, they provide ecosystem services that contribute to the wellbeing of millions of people, supporting productive fisheries, tourism, coastal defence, and cultural values (Moberg and Rönnbäck, 2003). Approximately $10 \%$ of the world's coral reef resources are found in the Wider Caribbean, where 43 million people live within $30 \mathrm{~km}$ of a reef (Burke et al. 2011). Small-scale fisheries, often targeting reefrelated species, are prevalent, contributing to employment and food security (Fanning et al., 2013). The Caribbean is also the world's most tourism-dependent region, with marine resources attracting $57 \%$ of scuba diving tours worldwide (UNEP, 2006). Caribbean reefs have experienced particularly rapid and well-documented ecological decline (Alvarez-Filip et al., 2011; Gardner et al., 2003). Growing demands for reef-related ecosystem services brought on by rapid population expansion, and disproportionally large predicted impacts from climate change at these latitudes further jeopardise the region's future (Eakin et al., 2010; Mora, 2008).

Improved governance is considered critical to future management effectiveness and ultimately the survival of coral reefs (Bruno, 2013; Graham et al., 2014). Current failure to address reef degradation and manage anthropogenic impacts has led to calls for improved management and governance of Caribbean coral reefs at local, national and regional levels (Heileman, 2011; Mahon et al., 2014; Mumby and Steneck, 2008). As one of the most geopolitically diverse regions in the world, diverse marine resource governance arrangements and challenges exist (Fanning et al., 2009; McConney et al., 2007). Actors are involved at many levels, from local level community-based organisations to government departments and international bodies. Consequently, complex jurisdictions and responsibilities among formal and informal sectors often overlap or compete (CARSEA, 2007; Fanning et al., 2007). This paper contributes to building good governance arrangements at local to national levels by developing an improved understanding of 'good governance' as perceived by community members. 


\subsection{Study sites}

Research was designed to collect data capturing some of the diversity of coastal communities in the Wider Caribbean Region. Four countries, Barbados, St Kitts and Nevis, Belize, and Honduras, were selected to represent diverse social and economic conditions, and levels of marine resource dependency (Figure 1). The four study countries vary in their governance arrangements for coral reefs and the degree of marine conservation implemented, illustrated in part by differences in the number of marine protected areas (MPAs) and actors involved in reef management activities (Table 3).

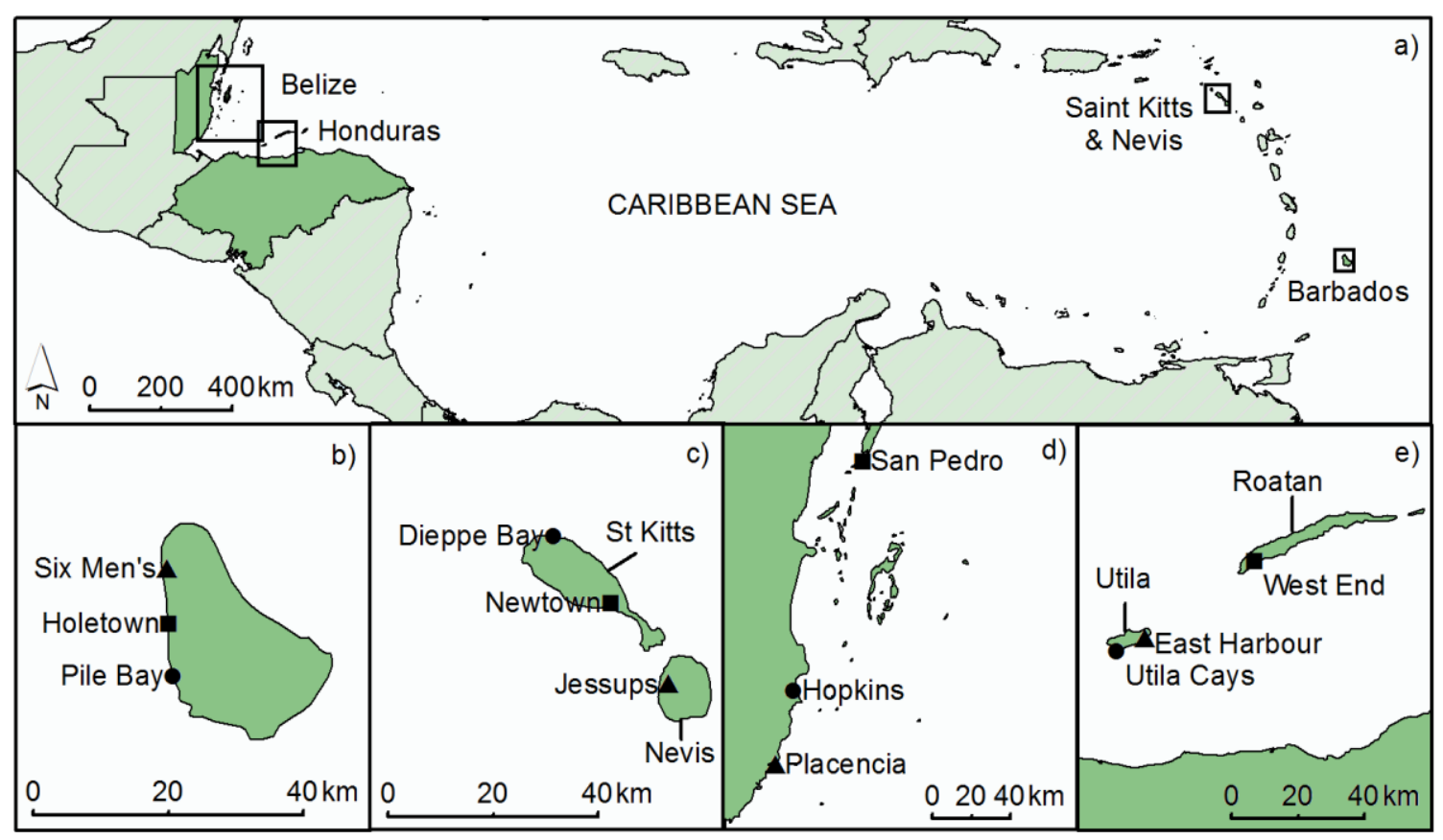

Figure 1. Maps of a) study countries, and b-e) study sites within Barbados, St Kitts and Nevis, Belize and Honduras, respectively. Circles indicate predominantly fishing communities, squares predominantly tourism, and triangles a mixture of the two.

Table 3. Example data to highlight the advancement of marine management and governance structures relating to reef management in each of the four study countries

\begin{tabular}{|c|c|c|c|c|}
\hline \multirow[t]{2}{*}{ Characteristics of marine governance } & \multicolumn{4}{|l|}{ Country } \\
\hline & Barbados & $\begin{array}{l}\text { St Kitts and } \\
\text { Nevis }\end{array}$ & Belize & Honduras \\
\hline \multicolumn{5}{|l|}{ Marine resource conservation } \\
\hline Number of marine reserves ${ }^{a}$ & 1 & 1 & 19 & 18 \\
\hline Total marine area protected $\left(\mathrm{km}^{2}\right)^{\mathrm{a}}$ & 2.1 & 0 & 2,524 & 438 \\
\hline Sea area $\left(\mathrm{km}^{2}\right)^{\mathrm{b}}$ & 186,000 & 10,000 & 31,000 & 238,000 \\
\hline Percentage of sea area protected (\%) & $<0.01$ & 0.00 & 8.14 & 0.18 \\
\hline \multicolumn{5}{|l|}{ Organisations involved with reefs ${ }^{c}$} \\
\hline National govt. ministries/departments/institutes & 32 & 38 & 34 & 18 \\
\hline Local govt. departments/divisions/institutes & 0 & 0 & 2 & 9 \\
\hline National organisations & 10 & 17 & 28 & 15 \\
\hline Local organisations & 0 & 0 & 12 & 12 \\
\hline Regional organisations & 4 & 3 & 3 & 1 \\
\hline Non-governmental organisations & 4 & 6 & 15 & 19 \\
\hline Educational/university institutions & 2 & 4 & 4 & 2 \\
\hline Private interest/industry groups & 6 & 2 & 7 & 0 \\
\hline
\end{tabular}

${ }^{\mathrm{a}}$ Wood (2007)
$\mathrm{b}$ Spalding \& B

${ }^{\mathrm{b}}$ Spalding \& Bunting (2004)

${ }^{\mathrm{c}}$ data collected during national level consultation meetings in each country studied 
Three communities were studied per country. Site selection attempted to capture differences in reef resource use, selecting one site where reef use is predominantly reef fisheries, one where reef-related tourism is important, and one where a mixture of dependence was apparent (Figure 1).

\subsubsection{Small island states}

Barbados is a small island state, where national government departments are predominantly responsible for coral reef management (Table 3). National government departments are also the main actors responsible for coral reef management in St Kitts and Nevis, but federation of the two islands brings additional management complexity. Nevis has its own administration and government to manage at the island-level, but also some transboundary issues such as fisheries (Agostini et al., 2010). Due in part to the size of both Barbados and St Kitts and Nevis, there is little distinction between local and national level administration, and few actors are involved in reef management at a community level (Table 3). In Barbados, very few local level groups or organisations are involved in reef management. In St Kitts and Nevis, some fishers' cooperatives exist at island level, but there is little other organisation of resource users, and there were no local level organisations with direct relevance to coral reef management in the three communities studied.

\subsubsection{Continental states}

Belize's relatively small population also requires only national level government, although legally mandated town councils or more informal village councils may be involved in decision-making about local reef resources. A complex administrative structure allows many organisations, predominantly NGOs, to play a role in coastal and marine resource management (Brune and Sanders, 2008). A long history of marine protection (Cho, 2005) and many more local actors, NGOs and organisations (such as cooperatives) with a role in reef management, distinguish Belize from the island nations (Table 3). Co-management in Belize has occurred mainly by devolving authority to local NGOs (McConney et al., 2007). Marine resource users are also relatively well-organised, with the majority of fishers and tourism operators belonging to active fishing cooperatives or tour guide associations.

In contrast, while four actors at the national government level in Honduras are responsible for providing policies, legislation and regulations, local level government implements and enforces the regulations. The Bay Island study sites have local municipal government departments with some responsibility for decision-making, implementation and enforcement of reef management measures and local designation of protected areas. A large number of NGOs and local organisations also have roles or responsibilities relating to reef management, including co-management of MPAs. Resource users in Honduras are less organised in comparison to Belize.

\section{Methods}

\subsection{Data collection}

Collection of data on perceptions of reef governance formed part of a household survey $(n=871)$ using face-to-face semi-structured interviews undertaken in twelve communities between February 2011 and August 2012 (Table 4). The target sample in each community included up to 50 direct reef-resource users, and a minimum of 25 randomly selected community members, who were in many cases considered to be indirect resource users. Based on their level of dependency on reefs in the Caribbean, two groups of direct users were specifically targeted: reef fishers and reef-related tourism operators (Burke et al., 2011). Direct resource users were targeted primarily through opportunistic and snowball sampling (Bunce et al., 2000) but were selected to reflect the total numbers and balance (fishing vs. tourism) of resource users within each community. Fewer were interviewed only in communities with smaller populations or fewer resource users. Remaining respondents were targeted by randomly selecting households within defined community boundaries, using $100 \mathrm{~m} \times 100 \mathrm{~m}$ numbered grids and a random number generator. The sampling strategy was designed to ensure representation of direct resource users in the sample within each community, which could not have been achieved through random sampling alone due to the low density of fishing and tourism households in some sites. Data collection was undertaken by a consistent core of the authors, and two local research assistants, which changed in each country. All research assistants were trained by the core team, using comparable methods. Interviews were conducted in pairs to minimise any interviewer bias. 
Table 4. Summary of interviews $(n=871)$ conducted in twelve Caribbean communities during 2011-2012. Reef use columns indicate direct participation in reef use activity by respondent

\begin{tabular}{lllllll}
\hline \multirow{2}{*}{ Country } & Community & \multicolumn{2}{c}{ Reef use } & \multicolumn{3}{c}{ Total } \\
\cline { 3 - 6 } & & Fishing & Tourism & Both & Neither & \\
\hline Barbados & Holetown & 7 & 22 & 1 & 44 & 74 \\
& Pile Bay & 11 & 2 & 1 & 30 & 44 \\
Belize & Six Men's & 14 & 6 & 5 & 48 & 73 \\
& Hopkins & 33 & 8 & 17 & 18 & 76 \\
Honduras & Placencia & 28 & 8 & 32 & 7 & 75 \\
& San Pedro & 15 & 13 & 33 & 15 & 76 \\
& East Harbour & 15 & 25 & 14 & 21 & 75 \\
St Kitts and Nevis & Utila Cays & 45 & 3 & 6 & 22 & 76 \\
& West End & 7 & 35 & 14 & 19 & 75 \\
& Dieppe Bay & 41 & 0 & 2 & 33 & 76 \\
& Jessups & 16 & 5 & 8 & 46 & 75 \\
& Newtown & 33 & 14 & 5 & 24 & 76 \\
\hline
\end{tabular}

Opening questions prompted respondents to consider who they perceived to be responsible for coral reef governance in their community. Respondents' perceptions of coral reef governance were then measured. Questions were designed to reflect established principles of good governance for natural resources. Piloting refined seven questions, each of which measured perceptions relating to one of the seven governance principles identified by Lockwood (2010) (Table 1). Binary responses were recorded and explanatory comments noted. Valid data were obtained from 868 interviews; three interviewees who did not respond to any of the seven questions were excluded from the analysis.

Review of the literature revealed five structural characteristics of reef governance arrangements. These were used to explicitly connect local governance structure and perceptions of governance principles. These were: presence of a government organisation, an active NGO, and resource user organisations; level of co-management (consultative, collaborative or delegated); and breadth of access to information. These characteristics were assessed in each community based on the indicators in Table 2 . Most indicators were assessed through a combination of secondary data, community profiles, and information from key informants involved in local reef governance. Social network metrics were used to indicate 'access to information', based on information-sharing relationships reported during interviews at both community level and national level. Two-step reach (Hanneman and Riddle, 2005) was calculated to measure the proportions of actors outside communities that were accessible to those inside, and categorised as low, medium or high (connected to $<20 \%, 20-39 \%, \geq 40 \%$ of outside actors within two steps or less).

\subsection{Data analysis}

Cronbach's reliability analysis was used to determine whether responses formed a coherent scale that effectively measured perceptions of governance processes. Coefficients range from 0 to 1, with values over 0.7 indicating a reliable measure of the underlying concept (Kline, 1999). Multiple correspondence analysis (MCA) was used to model a multivariate dataset of categorical variables to reveal underlying patterns among categories. Missing values were imputed using an iterative algorithm (Josse et al., 2012). MCA identifies dimensions of variation in the data comprising subsets of variables that are correlated with one another, but relatively independent of other variables. These dimensions can be interpreted as representing underlying factors that lead to patterns in responses, thus reducing complex sets of variables to fewer composite indicators. Each dimension identified was interpreted and labelled. Quantitative composite scores were calculated for each respondent on each dimension.

To explore the basis of differences in perceptions, the twelve communities studied were classified into similar groups, a scree plot indicating three clusters to be the most appropriate grouping structure. Data were aggregated by calculating mean scores for each MCA dimension within each community. These mean scores were used to group communities through cluster analysis using partitioning around medoids (Reynolds et al., 2006). Average silhouette widths of each cluster were used to assess cluster reliability; higher values indicate that observations are close to cluster centres and clusters are well separated (Kaufman and Rousseeuw, 2005). Communities falling within the same cluster reflected similarities among perceptions of governance. Higher scores on each 
dimension were interpreted as indicating more positive perceptions. Resulting clusters were compared to the five characteristics of reef governance arrangements in each community (Table 2). All statistical analyses were undertaken in $\mathrm{R}$ using the FactoMineR, missMDA and cluster packages (Husson et al., 2007; Lê et al., 2008; Maechler et al., 2013; R Core Team, 2013).

\section{Results}

\subsection{Measuring perceptions of good governance principles}

Valid responses recorded during interviews varied from $62 \%$ - $99 \%$ of interviewees for each statement. Cronbach's reliability analysis showed that responses to all seven questions formed a reliable scale of governance perceptions $(\alpha=0.74)$, which would not have been improved by removing any of the questions from the analysis (Table 5).

Table 5. Summary of resource user responses $(n=868)$ to 'good governance' statements in the twelve communities studied, in ascending order by governance score. Higher scores indicate more positive perceptions of governance. Overall governance score is calculated as the mean number of statements agreed with as a percentage of those responded to by each individual within a community, accounting for missing data at respondent level.

\begin{tabular}{|c|c|c|c|c|c|c|c|c|c|}
\hline \multirow[t]{2}{*}{ Country } & \multirow[t]{2}{*}{ Community } & \multicolumn{7}{|c|}{ Respondents agreeing with statement (\%) } & \multirow[t]{2}{*}{ Governance score } \\
\hline & & 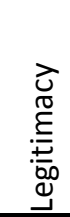 & 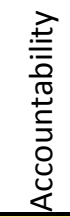 & 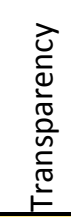 & 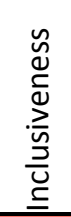 & 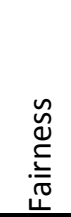 & 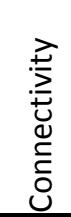 & 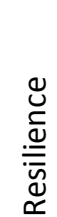 & \\
\hline Barbados & Holetown & 25 & 56 & 53 & 22 & 35 & 41 & 40 & 35 \\
\hline Barbados & Pile Bay & 18 & 39 & 57 & 33 & 36 & 42 & 47 & 38 \\
\hline St Kitts and Nevis & Dieppe Bay & 39 & 40 & 43 & 36 & 38 & 40 & 56 & 40 \\
\hline Barbados & Six Men's & 31 & 51 & 51 & 43 & 43 & 43 & 60 & 44 \\
\hline St Kitts and Nevis & Jessups & 38 & 46 & 60 & 27 & 42 & 59 & 49 & 46 \\
\hline St Kitts and Nevis & Newtown & 42 & 47 & 56 & 35 & 41 & 43 & 60 & 46 \\
\hline Honduras & East Harbour & 60 & 63 & 54 & 42 & 51 & 53 & 46 & 52 \\
\hline Honduras & Utila Cays & 65 & 74 & 39 & 34 & 69 & 55 & 56 & 55 \\
\hline Belize & Hopkins & 68 & 61 & 59 & 61 & 39 & 58 & 55 & 56 \\
\hline Belize & Placencia & 79 & 79 & 66 & 69 & 52 & 61 & 74 & 68 \\
\hline Honduras & West End & 65 & 87 & 64 & 67 & 63 & 63 & 72 & 68 \\
\hline Belize & San Pedro & 76 & 71 & 63 & 65 & 66 & 73 & 71 & 69 \\
\hline
\end{tabular}

In total, respondents agreed with $34-68 \%$ of all statements in each community (Table 5). The lowest overall agreement was in the community of Holetown in Barbados, and the highest in San Pedro, Belize. A clear geographic pattern was evident in perceptual differences, low scores from Eastern Caribbean communities on the islands of Barbados and St Kitts and Nevis contrasting with high scores in Belizean and Honduran communities in the Western Caribbean.

Agreement with each individual statement ranged from $18 \%$ to $87 \%$ in each community. The widest variance in response related to the question reflecting legitimacy, to which between $18-79 \%$ of respondents agreed that the organisations in charge of reef management were performing well (Table 5). Relatively low scores were recorded for the principles of fairness and inclusiveness, with fewer than $50 \%$ of respondents in the majority of communities perceiving that rules were enforced fairly, or that they had an opportunity to participate in management decisions (Table 5). Comparatively higher scores were recorded for accountability, transparency, connectivity and resilience. The proportion of respondents perceiving reef management to be accountable was particularly high in West End, Honduras (87\%; Table 5). 
Multiple correspondence analysis identified two underlying dimensions that together explained $58.9 \%$ of the variation in responses (Table 6). The first dimension, accounting for $39.8 \%$ of the variance, represented respondents' general perceptions of whether good governance principles were operational in current reef management arrangements. This first dimension was most highly correlated with perceptions of legitimacy (Table 6). This was followed by perceptions of transparency, fairness and connectivity; both positive and negative perceptions of these principles contributed to the first dimension. The principle of resilience was more weakly correlated with the first dimension, while accountability and inclusiveness had loadings below 0.25 (Table 6). We interpret this first dimension as representing "institutional acceptance" (DeCaro and Stokes, 2013). It measures the degree to which community members endorse current reef governance processes.

The second dimension, accounting for $19.1 \%$ of the variance, represented respondents' perceptions of their own engagement in reef management. This dimension was most strongly correlated with accountability, or respondents' ability to challenge rules or decisions, and hold managers accountable for reef management actions (Table 6). This was followed by inclusiveness, reflecting respondents' perceived ability to participate in decisions made about coral reef management (Table 6). This second dimension is directly reflective of concepts of engagement in contemporary literature, and is referred to as "engagement" (Jentoft et al., 1998; Pomeroy and Douvere, 2008; Ritchie and Ellis, 2010).

\subsection{Governance clusters and associated governance structures}

Analysis identified three clusters of communities in which perceptions of governance were similar (Figure 2; Table 6). Clusters one and three had average silhouette widths of 0.81 and 0.66 , indicating a strong and reasonable degree of structure respectively (Kaufman and Rousseeuw, 2005). In contrast, cluster two had an average silhouette width of 0.19 , suggesting a lack of substantial structure, illustrated by the distance between communities (Figure 2).

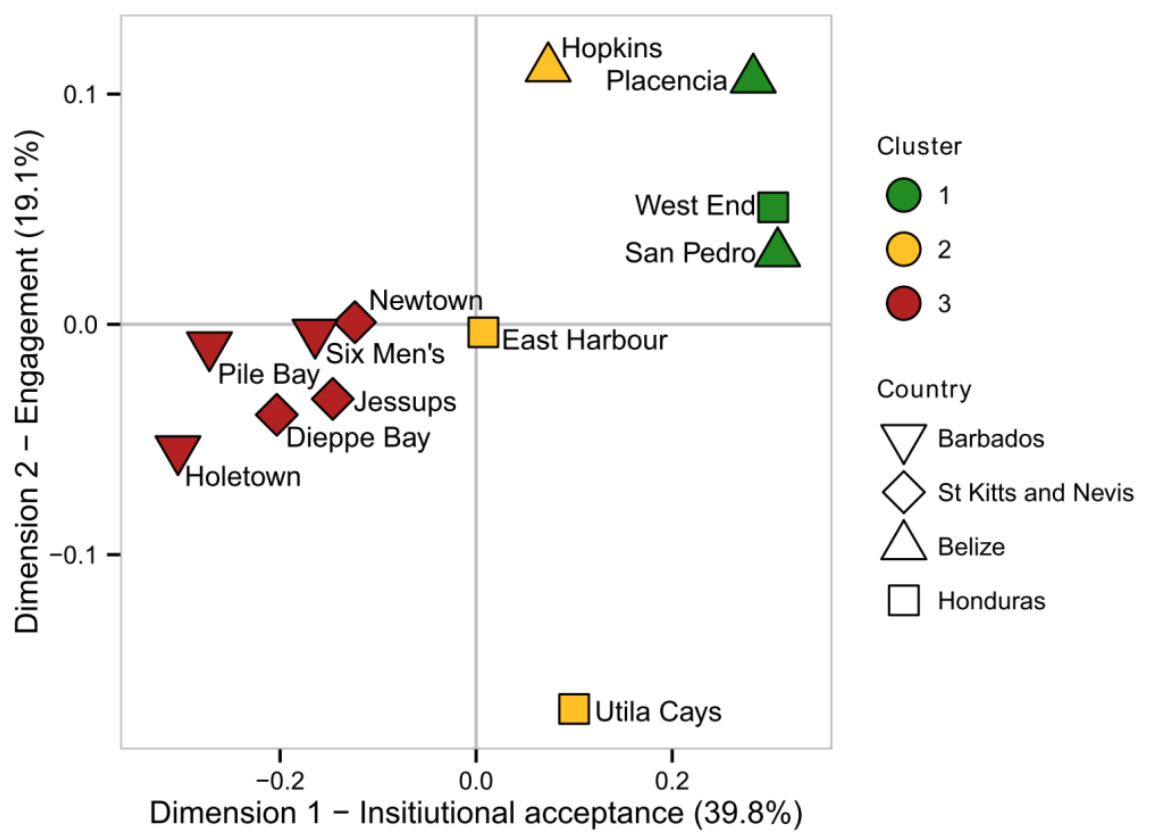

Figure 2. Mean scores on first and second MCA dimensions at each community. Colour indicates cluster assignment based on cluster analysis; symbol indicates country.

The three communities in cluster one scored highly on both dimensions, indicating relatively positive perceptions of both reef governance processes and engagement (Figure 2). Cluster two contained three communities with mid-level scores on dimension one and highly varied scores on dimension two. Cluster three contained six of the twelve communities, and included those with relatively low scores on both dimensions, indicating that on average, members of these communities had relatively negative perceptions of reef governance. 
Table 6. Summary of responses to questions measuring perceptions of reef governance among households $(n=868)$, reliability analysis using Cronbach's alpha ( $\alpha$ ), and results of multiple correspondence analysis. Cronbach's reliability measures report correlation of each variable with the total scale (item-total correlation) and the effect of removing each variable on the overall value of alpha ( $\alpha$ if dropped). MCA results report the squared correlation ratio between categorical variable and dimension $\left(R^{2} ;\right.$ values $<0.25$ are not reported; $p<0.001$ for all variables), the coordinates of each variable category on dimensions one and two, and the contribution of each category to each dimension (higher values indicate greater contribution). Remaining columns show the percentage of respondents agreeing with each statement overall, and in each of the three clusters of communities identified.

\begin{tabular}{|c|c|c|c|c|c|c|c|c|c|c|c|c|c|c|}
\hline \multirow[t]{2}{*}{$\begin{array}{l}\text { Governance } \\
\text { principle }\end{array}$} & \multirow[t]{2}{*}{$\begin{array}{l}\text { Responses } \\
\text { (n) }\end{array}$} & \multicolumn{2}{|c|}{$\begin{array}{l}\text { Cronbach's reliability } \\
\text { analysis }\end{array}$} & \multicolumn{2}{|c|}{$\begin{array}{l}\mathrm{R}^{2} \text { for } \mathrm{MCA} \\
\text { dimensions }\end{array}$} & \multirow[t]{2}{*}{$\begin{array}{l}\text { Response } \\
\text { category }\end{array}$} & \multicolumn{2}{|c|}{ Coordinate } & \multicolumn{2}{|c|}{ Contribution } & \multicolumn{4}{|c|}{ Respondents agreeing with statement (\%) } \\
\hline & & $\begin{array}{l}\text { Item-total } \\
\text { correlation }\end{array}$ & $\begin{array}{l}\alpha \text { if } \\
\text { dropped }\end{array}$ & $\begin{array}{l}\operatorname{Dim} .1 \\
39.8 \%\end{array}$ & $\begin{array}{l}\operatorname{Dim} .2 \\
19.1 \%\end{array}$ & & $\operatorname{Dim} 1$ & $\operatorname{Dim} 2$ & $\operatorname{Dim} 1$ & $\operatorname{Dim} 2$ & Overall & Cluster 1 & Cluster 2 & Cluster 3 \\
\hline \multirow[t]{2}{*}{ Legitimacy } & 655 & 0.69 & 0.63 & 0.47 & & Yes & 0.55 & -0.14 & 7.92 & 1.13 & 62 & 73 & 64 & 33 \\
\hline & & & & & & No & -0.83 & 0.22 & 11.91 & 1.70 & & & & \\
\hline \multirow[t]{2}{*}{ Transparency } & 741 & 0.63 & 0.65 & 0.41 & & Yes & 0.64 & 0.17 & 8.99 & 1.27 & 52 & 79 & 66 & 47 \\
\hline & & & & & & No & -0.68 & -0.18 & 9.54 & 1.35 & & & & \\
\hline \multirow[t]{2}{*}{ Accountability } & 722 & 0.43 & 0.71 & & 0.50 & Yes & 0.25 & -0.73 & 1.51 & 18.66 & 55 & 64 & 50 & 53 \\
\hline & & & & & & No & -0.30 & 0.62 & 1.78 & 22.10 & & & & \\
\hline \multirow[t]{2}{*}{ Inclusiveness } & 778 & 0.55 & 0.68 & & 0.39 & Yes & 0.55 & 0.67 & 5.84 & 18.42 & 46 & 67 & 46 & 33 \\
\hline & & & & & & No & -0.46 & -0.56 & 4.87 & 15.37 & & & & \\
\hline \multirow[t]{2}{*}{ Fairness } & 672 & 0.63 & 0.65 & 0.40 & & Yes & 0.68 & -0.33 & 9.47 & 4.72 & 50 & 61 & 53 & 39 \\
\hline & & & & & & No & -0.62 & 0.30 & 8.69 & 4.33 & & & & \\
\hline \multirow[t]{2}{*}{ Connectivity } & 692 & 0.61 & 0.66 & 0.38 & & Yes & 0.58 & -0.30 & 7.71 & 4.18 & 53 & 65 & 55 & 44 \\
\hline & & & & & & No & -0.65 & 0.33 & 8.57 & 4.64 & & & & \\
\hline \multirow[t]{2}{*}{ Resilience } & 541 & 0.63 & 0.65 & 0.28 & & Yes & 0.48 & -0.13 & 5.59 & 0.90 & 58 & 53 & 49 & 40 \\
\hline & & & & & & No & -0.64 & 0.18 & 7.59 & 1.21 & & & & \\
\hline
\end{tabular}


Communities in cluster one had high mean scores on almost all indicators, particularly legitimacy and transparency (Table 6). Communities in cluster three had low scores on both underlying governance components, with particularly low levels of legitimacy and inclusiveness perceived (Table 6). These principles drove the biggest differences between clusters one and three. A third more respondents had positive perceptions of legitimacy and inclusiveness in cluster one than three. In contrast, comparable scores were identified across all three clusters for perceived accountability.

Communities within each cluster had a number of common governance arrangements for reef management (Table 7). None of the communities in cluster three had an active NGO presence. Only one of these communities had developed a resource user organisation. In contrast, all three communities in cluster one had an active NGO present, management decision-making delegated to the local level, and active resource user organisations. Access to information was variable within clusters. All communities in cluster one had high levels of access to information about coral reefs and their management from actors outside the community, as did two communities in cluster three, while two communities in the second cluster had low access (Table 7).

Table 7. Characteristics of coral reef governance arrangements in the twelve communities studied. NGO = non-governmental organisation present in community; GO = governmental organisation present in community; degree of co-management based on typology outlined by Pomeroy et al. (2004); access to information is based on reported information-sharing relationships between community-level actors and outside organisations or departments.

\begin{tabular}{llllllll}
\hline Country & Community & Cluster & GO & NGO & $\begin{array}{l}\text { Resource user } \\
\text { organisation }\end{array}$ & $\begin{array}{l}\text { Access to } \\
\text { information }\end{array}$ & $\begin{array}{l}\text { Degree of } \\
\text { co-management }\end{array}$ \\
\hline Belize & Placencia & 1 & No & Yes & Yes & High & Delegated \\
Belize & San Pedro & 1 & Yes & Yes & Yes & High & Collaborative \\
Honduras & West End & 1 & No & Yes & Yes & Lelegated & Collaborative \\
Belize & Hopkins & 2 & No & No & Yes & Medium & Delegated \\
Honduras & East Harbour & 2 & Yes & Yes & No & Low & Delegated \\
Honduras & Utila Cays & 2 & No & No & No & High & Consultative \\
Barbados & Holetown & 3 & Yes & No & No & High & Consultative \\
Barbados & Pile Bay & 3 & No & No & Yes & Medium & Consultative \\
Barbados & Six Men's & 3 & No & No & No & Low & Consultative \\
St Kitts and Nevis & Dieppe Bay & 3 & No & No & No & Low & Consultative \\
St Kitts and Nevis & Jessups & 3 & No & No & No & Medium & Consultative \\
St Kitts and Nevis & Newtown & 3 & Yes & No & No & &
\end{tabular}

\section{Discussion}

\subsection{Measuring perceptions of good governance principles}

This study uniquely contributes to the current debate on good governance for effective natural resource management by developing metrics for community perceptions of the application of governance principles. Responses formed a coherent scale across twelve Caribbean communities. Diverse opinions on the application of governance principles were expressed both within and between the study communities. Opinions differed even where structural arrangements for coral reef governance were the same, suggesting that other contextual factors or individual variables also shaped perceptions.

A strong geographic pattern emerged. Communities in the western Caribbean continental countries of Belize and Honduras showed more positive perceptions of governance principles than the two eastern Caribbean island countries, Barbados and St Kitts and Nevis. This may result from a number of factors, including: differences in national level governance approaches; willingness of national governments to delegate authority to a local level; levels of prioritisation, and associated resources and capacity afforded to coral reef management; and differences in socio-economic conditions and resource use (Cinner et al., 2012a; Pomeroy et al., 2001). In Barbados and St Kitts and Nevis, where top-down two-tier structures characterise governance, institutional acceptance by community members was relatively low. In comparison, Belize and Honduras had more complex governance structures and displayed higher institutional acceptance. Perceived engagement followed a similar pattern, perhaps due to a greater number of local level actors to facilitate participation of community members in more complex governance systems, but greater variability among communities suggests dependence on local societal factors. 


\subsection{Underlying themes driving differences in perceptions}

Despite governance complexity, institutional acceptance and engagement together explained over $50 \%$ of the variation in the perceptions data.

\subsubsection{Institutional acceptance}

Governance principles corresponding to the first dimension were legitimacy, transparency, fairness, connectivity and resilience. This axis was indicative of respondents' perceptions of the application of the principles by coral reef managers and institutions. It represents perceptions of the current governance system, as community members view it from an external perspective. It thus provides an indication of institutional acceptance (DeCaro and Stokes, 2013). Strong divergence in opinions on the legitimacy of governance processes characterises this dimension, reflecting community members' endorsement of managers' overall performance. This has significant implications for compliance, likely to be particularly important in communities where enforcement capacity is limited (Dietz et al., 2003; Salas et al., 2007). Greater legitimacy of management systems, drawn from loyalty among those being governed (Raakjær Nielsen, 2003), confers a degree of authority to governing systems and contributes to greater compliance with rules and regulations (Hønneland, 2000; Pollnac et al., 2010).

The question measuring legitimacy assessed 'output legitimacy', or the ability of managers to lead effectively and produce desired outcomes (Lockwood, 2010). Overlap among good governance principles means that other aspects of legitimacy are reflected in responses to subsequent questions. For example, transparency, a recognised mechanism to improve legitimacy (Biermann et al., 2010), measured whether decisions about coral reef management and the reasoning behind those decisions were perceived to be accessible by community members (Lockwood, 2010). Analysis at country level in a fisheries context has shown that the degree of transparency of policy processes has a significant effect on fisheries sustainability (Mora et al., 2009). Fairness, a key component of procedural legitimacy (Raakjær Nielsen, 2003), also contributed to dimension one. In the majority of communities, fewer than 50\% of respondents agreed that enforcement was fair. In many cases this was attributed to tensions between law enforcement and social relationships in small communities, enforcement officers being seen to be more lenient with preferred individuals. This is consistent with other studies (e.g. Korda et al. 2008), and has important implications as perceptions of fairness are a key determinant of compliance with management measures and maintaining legitimacy (Pomeroy et al., 2001; Raakjær Nielsen, 2003).

Connectivity and resilience were less strongly correlated with dimension one. The lowest scores for connectivity reflected competing interests among stakeholders, and a lack of cooperation among responsible agencies. Connectivity among actors involved in reef management is believed to facilitate the process of working through conflicts and problems, enabling a wider range of views to be accounted for in decision-making (Crona and Hubacek, 2010; Hartley, 2010; Lockwood, 2010). In cases where stakeholders perceive poor connectivity, trust and communication may be limited. Finally, lack of resilience in the coral reef management system also contributed to this dimension. Specifically, a perception that managers do not have plans in place to respond to future change. Peoples' belief that managers are proactively protecting them may lead to increased approval of governance systems, strengthening managerial authority (Lockwood, 2010). Conversely, legitimacy is eroded where managers' ability to respond to anticipated future threats is perceived to be limited.

\subsubsection{Engagement}

Aspects of governance principles corresponding to dimension two, engagement, included respondents' perceived ability to participate in decisions (inclusiveness), and opportunities to challenge rules or decisions made about coral reefs (accountability). These principles both represent important elements of the relationship between the governing system and community members, and have significant implications for effective coral reef governance. Greater inclusiveness is expected to lead to more democratic decision-making and thus greater legitimacy of resulting rules and regulations, conferring broader support for management and greater ecological effectiveness (Hønneland, 2000; Jentoft, 2007; McClanahan et al., 2008). Genuinely inclusive governance processes should take steps to include marginalised stakeholders (Lockwood, 2010), and the diversity of responses within all communities studied here suggests further research is needed to explore whether this is occurring. Accountability is also a central principle to the concept of engagement, particularly downward accountability of decentralised management bodies, which can help increase participation and empowerment of relevant stakeholders (Béné et al., 2009). Multiple avenues of accountability may be necessary where many actors play a role in governing complex systems such as coral reefs (Lockwood et al., 2012). 
This study successfully measured community perceptions of principles guiding governance processes. Two underlying themes broadly reflect perceptions of 1) acceptance of, and 2) level of engagement with, the institutional structures and processes for coral reef management. That the perceptions measured can be distilled into these two themes reflects the overlapping nature of good governance principles (Graham et al., 2003). The interview questions each reflected only one of several possible performance outcomes for each principle, thus the results are not reflective of all aspects of good governance principles. Further studies would be useful to examine whether the themes identified are consistent if perceptions of a broader range of good governance elements are considered.

Variation in the responses to questions not captured by the two themes may be a result of differences in individual experiences of governance processes among community members (e.g. direct versus indirect resource users), or different preferences regarding level of engagement in reef management activities. Further research is needed to explore factors determining individual-level perceptions. One difficulty in evaluating governance interactions is in identifying any one specific process to be evaluated, as multiple governance processes occur between different actors at different spatial and temporal scales (Rauschmayer et al., 2009). This study collected a general perspective on a broad range of governance processes and interactions with respect to coral reef governance. This may mask finer scale differences, particularly where there are a large number of actors involved in reef management (Table 3) and respondents may differently conceptualise what constitutes local reef governance. This study recorded perceptions as binary responses; however, issues of governance are rarely absolute, and future research could explore more nuanced perceptions of interactions at different stages of decision-making processes.

Despite limitations, the measurable themes described provide initial indicators of governance quality as perceived by communities. These contribute to understanding of the social fit of institutional arrangements to local circumstances, providing new insights on marine resource governance. Social fit may influence support for human behaviour, including management and compliance with regulations, therefore there are significant implications for governance outcomes. As they are based on qualitative perceptions, such aggregate indicators based on underlying themes are expected to be more robust than individual indicators in shedding light on broad concepts, and have potential to draw attention to communities facing governance challenges (Kaufmann et al., 2000).

Perceptions are inevitably subjective, and may shift with both change in governance practice and levels of awareness among those governed. They nevertheless provide information on the viewpoints of those whose resource use is influenced by governance arrangements (Korda et al., 2008). Perceptions shed light on the relationships between the 'governing system' and the 'system-tobe-governed', which includes community members as well as the natural resources being managed (Jentoft, 2007). Since resource governance involves regulating human activity, and perceptions influence behaviour (Coulthard, 2012; Schwarz et al., 2011), important implications for both management effectiveness and future developments in reef governance are highlighted. Understanding community-level perceptions may help managers to identify areas in which local governance could be improved to engender greater support. For example, developing context appropriate forms of engagement is important in establishing and maintaining institutions that fit local circumstances (DeCaro and Stokes, 2013; Lebel et al., 2006; Ostrom, 2010; Pomeroy and Douvere, 2008).

\subsection{Governance clusters and associated governance structures}

Three clusters reflected different perceptions of governance process among communities. These were consistent with theoretical perspectives suggesting that many of the characteristics of co-management are congruent with principles of good governance (Berkes, 2007; Plummer et al., 2012). Commonalities within clusters suggest community perceptions validate theoretical arguments that certain structural characteristics of governance systems lead to improved governance quality. Communities with the most positive perceptions of governance process shared four of the five structural characteristics measured.

First, a strong NGO presence; this may provide leadership in a community, helping build partnerships among stakeholders by facilitating communication and the development of trust, as well as connecting local stakeholders to actors at broader scales (Folke et al., 2005). In contrast, the presence of a local government organisation, which we hypothesised may support co-management and provide connections to broader government institutions (Pomeroy, 2007), did not appear to differ between clusters. Second, active resource user organisations may facilitate greater participation in reef management by stakeholders, and are considered critical to the development of co-management in the Caribbean (Pomeroy, 2007). Third, high levels of access to information from external networks can enhance collaboration, provide opportunities for inclusion of different perspectives, and enable development of common perspectives to inform decision-making (Evans, 2010; Folke et al., 2005). Communities with better links to external networks are expected to have greater access to information that informs effective decision-making about reef management (Bodin 
et al., 2006; Sandstrom and Rova, 2010). Fourth, delegated co-management arrangements may help support greater involvement of a wide range of actors in decision-making, leading to a more democratic decision-making process, incorporation of local knowledge, and facilitation of adaptive management (Folke et al., 2005; Pomeroy et al., 2004).

Cluster one demonstrated structural characteristics of governance systems associated with positive perceptions. Communities in this cluster, comprising Placencia and San Pedro in Belize, and West End in Honduras, shared greater institutional acceptance and positive perceptions of engagement. Though funding and staff to enforce regulations are limited (Cooper et al., 2009), the effectiveness of marine protection in Belize is judged as 'fair' (HRI, 2014). All communities studied scored highly on the dimension of institutional acceptance, perceiving coral reef management structures to be performing according to principles of good governance. These communities also perceived themselves as more engaged in coral reef management. Belize has a long history of marine protection and co-management, and since 2003 the National Integrated Coastal Zone Management Strategy has made explicit multiple engagement-related objectives (Cho, 2005). Belizean communities in this cluster had access to multiple local level organisations involved in reef management, many of which have a long history of working with local stakeholders. In Honduras, institutional acceptance and perceived engagement were most positive in the community of West End, where local NGO and comanager 'Roatan Marine Park' was established by community members and stakeholders, is highly active and centrally placed in the community.

In contrast, cluster three, comprising communities in Barbados and St Kitts and Nevis, shared relatively negative perceptions in terms of both institutional acceptance and engagement in coral reef management, and displayed a lack of many of the structural characteristics expected to facilitate good governance. Low institutional acceptance reflected respondents' perceptions of competing interests and lack of cooperation among management agencies, and a lack of coral reef management organisations at a local level. In Barbados, these perceptions are supported by studies suggesting that environmental legislation and its enforcement in Barbados lack integration (Khan and Alleyne, 1996). Similarly in St Kitts and Nevis, much existing marine management is described as piecemeal and sectorally implemented, with a lack of mechanisms for inter-agency decision-making restricting capacity to respond to complex challenges (Agostini et al. 2010). Engagement was also perceived less positively; perceptions of inclusiveness were consistently lower in communities in cluster three. No NGOs or active reef-related civil society organisations were based in the study communities in Barbados or St Kitts and Nevis, with the exception of fisher organisations in Pile Bay and Newtown. A consultative approach by government departments also led to poor perceptions of inclusiveness and accountability. Research in Barbados identified low levels of trust in government and among resource users (McConney et al., 2007), which may influence perceptions.

Cluster two was less coherent, but a number of communities in clusters two and three shared some of the characteristics found in cluster one, supporting the contention that a combination of factors is needed to support good governance process (Folke et al., 2005). There may be a greater chance of achieving efficient, equitable and sustainable outcomes where more conditions of effective governance structures are satisfied (Pomeroy, 2007). While certain institutional arrangements may be expected to be more conducive to the successful operationalisation of good governance principles, governance processes may vary independently of structural arrangements. For example, though co-management is expected to improve legitimacy and compliance in fisheries, the implementation of a particular institutional structure may not always secure the expected outcome (Jentoft, 2000). In the communities studied, both West End and East Harbour in Honduras shared similar delegated reef management decision-making processes and had a local NGO presence, yet there were large differences in perceptions of governance processes, particularly with respect to accountability, inclusiveness and resilience. Differences may be attributed to marine management authorities in East Harbour being perceived as ineffective (Korda et al., 2008). Outlying Utila Cays was characterised by particularly low perceived engagement, attributable to low capacity within the community to engage in natural resource management (Cuthill and Fien, 2005; Mackinson et al., 2011). Yet, relatively high institutional acceptance reflected the presence of a strongly advocatory local mayor. When a strong advocate or agent is present, direct engagement of community members in decision-making may not always be necessary to achieve support for governance mechanisms (DeCaro and Stokes, 2013).

\subsubsection{Implications}

Cluster analysis has provided unique evidence linking community members' perceptions of good governance principles with structural characteristics of existing governance arrangements, across multiple countries and communities. Important policy implications for managers seeking to identify areas of governance to be targeted for improvements are evident. Clusters highlight characteristics of governance systems which are positively perceived. That perceptions of principles also varied independently of structural arrangements highlights that governance is an uncertain endeavour; operationalising 'good practices' may not guarantee success in complex, nested social-ecological systems (Ostrom 2007). The present evidence supports the need to match institutions to local circumstances (DeCaro and Stokes, 2013; Ostrom, 2007). This can help ensure public participation, recognised as important in developing and maintaining such institutions (Ostrom, 2010). Identifying drivers behind human motivation to actively engage in 
governance processes has the potential to considerably enhance the effectiveness of reef management, developing participatory structures that are responsive to current challenges (Berrang-Ford et al., 2011).

\section{Conclusion}

Caribbean coral reefs and the communities dependent on them are among many social-ecological systems facing increasing threats in the context of global environmental change and growing demand for resources. Improved governance arrangements are essential if the causes of environmental decline are to be addressed and effective responses made to current and future threats. This study explored community members' perceptions of good governance principles, and developed a robust scale to measure perceptions of governance quality. It identified communities with similar patterns of responses, and examined associated structural characteristics of governance. This paper provides new understanding of how community members perceive reef governance quality in the Caribbean, and shows how perceptions relate to diverse governance arrangements. The themes of institutional acceptance and engagement, reflecting community members' endorsement of the governance system and their involvement with it, together with the structural characteristics supporting positive perceptions of these themes, provide insight into the quality of governance and institutional fit. Ecosystem complexity of coral reefs and well-documented Caribbean declines, coupled with heavy reliance of societies on a degraded common pool resource, make this case study relevant to initiatives to understand and improve governance in other complex resource systems. Understanding community perceptions of governance can help improve management effectiveness and capacity to respond to change, for example, by engendering benefits such as greater support for natural resource management measures. These insights have important implications for the design of successful management systems and governance structures for sustainable resource use.

\section{Acknowledgements}

We are grateful for the generosity and hospitality of the Caribbean communities who gave their time for interviews, and numerous partners and collaborators in each country who supported the research team. D Gill, M Phillips, R Ford, S Bonilla, S Brune, S Gardiner, J Pollock, L Chicas, C Guerrero, C Barrow and C Hinds assisted with data collection and data entry. Thanks to N Polunin for useful comments on an earlier version of this manuscript, and to two anonymous reviewers, whose comments greatly improved the paper. The research leading to these results has received funding from the European Union $7^{\text {th }}$ Framework programme (P7/20072013) under grant agreement No. 244161.

\section{References}

Agostini, V.N., Margles, S.W., Schill, S.R., Knowles, J.E., Blyther, R.J., 2010. Marine Zoning in Saint Kitts and Nevis: A Path Towards Sustainable Management of Marine Resources. The Nature Conservancy.

Agrawal, A., 2001. Common Property Institutions and Sustainable Governance of Resources. World Dev. 29, $1649-1672$. doi:10.1016/S0305-750X(01)00063-8

Alvarez-Filip, L., Côté, I.M., Gill, J.A., Watkinson, A.R., Dulvy, N.K., 2011. Region-??wide temporal and spatial variation in Caribbean reef architecture: is coral cover the whole story? Glob. Chang. Biol. 17, 2470-2477. doi:10.1111/j.1365-2486.2010.02385.x

Anderies, J.M., Janssen, M., Ostrom, E., 2004. A Framework to Analyze the Robustness of Social-ecological Systems from an Institutional Perspective. Ecol. Soc. 9.

Armitage, D., Berkes, F., Doubleday, N., 2007. Adaptive Co-management: Collaboration, Learning, and Multi-level Governance. UBC Press, Vancouver, Canada.

Basurto, X., 2013. Linking multi-level governance to local common-pool resource theory using fuzzy-set qualitative comparative analysis: Insights from twenty years of biodiversity conservation in Costa Rica. Glob. Environ. Chang. 23, 573-587. doi:10.1016/j.gloenvcha.2013.02.011

Basurto, X., Gelcich, S., Ostrom, E., 2013. The social-ecological system framework as a knowledge classificatory system for benthic small-scale fisheries. Glob. Environ. Chang. 23, 1366-1380. doi:10.1016/j.gloenvcha.2013.08.001

Bavinck, M., Chuenpagdee, R., 2005. Current Governance Principles, in: Kooiman, J., Bavinck, M., Jentoft, S., Pullin, R. (Eds.), Fish for Life: Interactive Governance for Fisheries. Amsterdam University Press, Amsterdam, pp. 247-265.

Bavinck, M., Chuenpagdee, R., Degnbol, P., Pascual, J., 2005. Challenges and Concerns Revisited, in: Kooiman, J., Bavinck, M., Jentoft, S., Pullin, R. (Eds.), Fish for Life: Interactive Governance for Fisheries2. Amsterdam University Press, Amsterdam, pp. 305-325.

Béné, C., Belal, E., Baba, M.O., Ovie, S., Raji, A., Malasha, I., Njaya, F., Na Andi, M., Russell, A., Neiland, A., 2009. Power Struggle, Dispute and Alliance Over Local Resources: Analyzing "Democratic" Decentralization of Natural Resources through the Lenses of Africa Inland Fisheries. World Dev. 37, 1935-1950. doi:10.1016/j.worlddev.2009.05.003

Berkes, F., 2007. Adaptive Co-Management and Complexity: Exploring the Many Faces of Co-Management, in: Armitage, D., Berkes, F., Doubleday, N. (Eds.), Adaptive Co-Management: Collaboration, Learning and Multi-Level Governance. UBC Press, Vancouver, BC, pp. 19-37. 
Berrang-Ford, L., Ford, J.D., Paterson, J., 2011. Are we adapting to climate change? Glob. Environ. Chang. $21,25-33$. doi:10.1016/j.gloenvcha.2010.09.012

Biermann, F., 2007. "Earth system governance" as a crosscutting theme of global change research. Glob. Environ. Chang. 17, 326337. doi:10.1016/j.gloenvcha.2006.11.010

Biermann, F., Betsill, M.M., Gupta, J., Kanie, N., Lebel, L., Liverman, D., Schroeder, H., Siebenhüner, B., Zondervan, R., 2010. Earth system governance: a research framework. Int. Environ. Agreements Polit. Law Econ. 10, 277-298. doi:10.1007/s10784-0109137-3

Bodin, Ö., Crona, B.I., Ernstson, H., 2006. Social networks in natural resource management: What is there to learn from a structural perspective? Ecol. Soc. 11.

Brune, S., Sanders, A., 2008. Vulnerability and Perceptions in the Coastal Communities of Belize: Case Study of San Pedro, Placencia and Port Loyola. WWF-CA - NOAA - EAP Zamorano.

Bruno, J.F., 2013. Coral reefs: Building a Better Crystal Ball. Curr. Biol. 23, R473-5. doi:10.1016/j.cub.2013.04.042

Bunce, L., Townsley, P., Pomeroy, R.S., Pollnac, R.B., 2000. Socioeconomic Manual for Coral Reef Management. www.aims.gov.au/pages/reflib/smcrm/mcrm-000.html, GCRMN/IUCN/AIMS/NOAA, AIMS, Townsville.

Burke, L., Maidens, J., 2004. Reefs at Risk in the Caribbean. World Resources Institute, Washington, D.C.

Burke, L., Reytar, K., Spalding, M., Perry, A.L., 2011. Reefs at Risk Revisited. World Resources Institute, Washington, D.C.

CARSEA, 2007. Caribbean Sea Ecosystem Assessment (CARSEA). A sub-global component of the Millennium Ecosystem Assessment (MA). J. Agard, A. Cropper, K. Garcia, eds., Caribbean Marine Studies, Special Edition, 2007. 104 pp.

Cash, D., Adger, W.N., Berkes, F., Garden, P., Lebel, L., Olsson, P., Pritchard, L., Young, O.R., 2006. Scale and Cross-Ccale Dynamics: Governance and Information in a Multilevel World. Ecol. Soc. 11.

Cho, L., 2005. Marine protected areas: a tool for integrated coastal management in Belize. Ocean Coast. Manag. 48, $932-947$. doi:10.1016/j.ocecoaman.2005.03.007

Chuenpagdee, R., 2011. Interactive Governance for Marine Conservation: An Illustration. Bull. Mar. Sci. 87, $197-211$. doi:10.5343/bms.2010.1061

Cinner, J.E., Basurto, X., Fidelman, P., Kuange, J., Lahari, R., Mukminin, A., 2012b. Institutional designs of customary fisheries management arrangements in Indonesia, Papua New Guinea, and Mexico. Mar. Policy 36, 278-285. doi:10.1016/j.marpol.2011.06.005

Cinner, J.E., McClanahan, T.R., MacNeil, M.A., Graham, N.A.J., Daw, T.M., Mukminin, A., Feary, D.A., Rabearisoa, A.L., Wamukota, A., Jiddawi, N., Campbell, S.J., Baird, A.H., Januchowski-Hartley, F.A., Hamed, S., Lahari, R., Morove, T., Kuange, J., $2012 a$. Comanagement of coral reef social-ecological systems. Proc. Natl. Acad. Sci. 109, 5219-5222. doi:10.1073/pnas.1121215109

Cooper, E., Burke, L., Bood, N., 2009. Coastal Capital: Belize. The economic contribution of Belize's coral reefs and mangroves. World Resources Institute, Washington DC. 53pp.

Costanza, R., 1998. Principles for Sustainable Governance of the Oceans. Science. 281, 198-199. doi:10.1126/science.281.5374.198

Coulthard, S., 2012. Can we be both resilient and well, and what choices do people have? Incorporating agency into the resilience debate from a fisheries perspective. Ecol. Soc. 17.

Crona, B., Hubacek, K., 2010. The right connections: how do social networks lubricate the machinery of natural resource governance? Ecol. Soc. 15.

Cuthill, M., Fien, J., 2005. Capacity building: Facilitating citizen participation in local governance. Aust. J. Public Adm. 64, 63-80.

Dale, A., Vella, K., Pressey, R.L., Brodie, J., Yorkston, H., Potts, R., 2013. A method for risk analysis across governance systems: a Great Barrier Reef case study. Environ. Res. Lett. 8, 015037. doi:10.1088/1748-9326/8/1/015037

Dalton, T., Forrester, G., Pollnac, R., 2012. Participation, process quality, and performance of marine protected areas in the wider Caribbean. Environ. Manage. 49, 1224-37. doi:10.1007/s00267-012-9855-0

DeCaro, D., Stokes, M., 2013. Public Participation and Institutional fit: A Social-Psychological Perspective. Ecol. Soc. 18.

Dietz, T., Ostrom, E., Stern, P.C., 2003. The Struggle to Govern the Commons. Science. 302, 1907-12. doi:10.1126/science.1091015

Eakin, C.M., Morgan, J.A., Heron, S.F., Smith, T.B., Liu, G., Alvarez-Filip, L., Baca, B., Bartels, E., Bastidas, C., Bouchon, C., Brandt, M., Bruckner, A.W., Bunkley-Williams, L., Cameron, A., Causey, B.D., Chiappone, M., Christensen, T.R.L., Crabbe, M.J.C., Day, O., de la Guardia, E., Díaz-Pulido, G., DiResta, D., Gil-Agudelo, D.L., Gilliam, D.S., Ginsburg, R.N., Gore, S., Guzmán, H.M., Hendee, J.C., Hernández-Delgado, E. a, Husain, E., Jeffrey, C.F.G., Jones, R.J., Jordán-Dahlgren, E., Kaufman, L.S., Kline, D.I., Kramer, P. a, Lang, J.C., Lirman, D., Mallela, J., Manfrino, C., Maréchal, J.-P., Marks, K., Mihaly, J., Miller, W.J., Mueller, E.M., Muller, E.M., Orozco Toro, C.A., Oxenford, H.A., Ponce-Taylor, D., Quinn, N., Ritchie, K.B., Rodríguez, S., Ramírez, A.R., Romano, S., Samhouri, J.F., Sánchez, J.A., Schmahl, G.P., Shank, B. V, Skirving, W.J., Steiner, S.C.C., Villamizar, E., Walsh, S.M., Walter, C., Weil, E., Williams, E.H., Roberson, K.W., Yusuf, Y., 2010. Caribbean corals in crisis: record thermal stress, bleaching, and mortality in 2005. PLoS One 5, e13969. doi:10.1371/journal.pone.0013969

Engle, N.L., Lemos, M.C., 2010. Unpacking governance: Building adaptive capacity to climate change of river basins in Brazil. Glob. Environ. Chang. 20, 4-13. doi:10.1016/j.gloenvcha.2009.07.001 
Evans, L., Cherrett, N., Pemsl, D., 2011. Assessing the impact of fisheries co-management interventions in developing countries: A meta-analysis. J. Environ. Manage. 92, 1938-49. doi:10.1016/j.jenvman.2011.03.010

Evans, L.S., 2010. Ecological knowledge interactions in marine governance in Kenya. Ocean Coast. Manag. 53, $180-191$. doi:10.1016/j.ocecoaman.2010.01.009

Fanning, L., Mahon, R., McConney, P., 2009. Focusing on Living Marine Resource Governance: The Caribbean Large Marine Ecosystem and Adjacent Areas Project. Coast. Manag. 37, 219-234. doi:10.1080/08920750902851203

Fanning, L., Mahon, R., McConney, P., 2013. Applying the large marine ecosystem (LME) governance framework in the Wider Caribbean Region. Mar. Policy 42, 99-110. doi:10.1016/j.marpol.2013.02.008

Fanning, L., Mahon, R., McConney, P., Angulo, J., Burrows, F., Chakalall, B., Gil, D., Haughton, M., Heileman, S., Martinez, S., Ostine, L., Oviedo, A., Parsons, S., Phillips, T., Santixo Arroya, C., Simmons, B., Toro, C., 2007. A large marine ecosystem governance framework. Mar. Policy 31, 434-443. doi:10.1016/j.marpol.2007.01.003

Folke, C., Hahn, T., Olsson, P., Norberg, J., 2005. Adaptive Governance of Social-Ecological Systems. Annu. Rev. Environ. Resour. 30, 441-473. doi:10.1146/annurev.energy.30.050504.144511

Gardner, T.A., Côté, I.M., Gill, J.A., Grant, A., Watkinson, A.R., 2003. Long-term region-wide declines in Caribbean corals. Science. 301, 958-60. doi:10.1126/science.1086050

Gelcich, S., Edwards-Jones, G., Kaiser, M.J., 2005. Importance of Attitudinal Differences among Artisanal Fishers toward CoManagement and Conservation of Marine Resources. Conserv. Biol. 19, 865-875. doi:10.1111/j.1523-1739.2005.00534.x

Gelcich, S., Edwards-Jones, G., Kaiser, M.J., Castilla, J.C., Kaiser, J., 2006. Co-management policy can reduce resilience in traditionally managed marine ecosystems. Ecosystems 9, 951-966. doi:10.1007/S10021-005-0007-8

Gelcich, S., Kaiser, M.J., Castilla, J.C., Edwards-Jones, G., 2008. Engagement in co-management of marine benthic resources influences environmental perceptions of artisanal fishers. Environ. Conserv. 35, 36-45. doi:10.1017/S0376892908004475

Graham, J., Amos, B., Plumptre, T., 2003. Governance Principles for Protected Areas in the 21st Century. Institute On Governance, Ottawa, Canada.

Graham, N.A., Cinner, J.E., Norström, A. V, Nyström, M., 2014. Coral reefs as novel ecosystems: embracing new futures. Curr. Opin. Environ. Sustain. 7, 9-14. doi:10.1016/j.cosust.2013.11.023

Gutiérrez, N.L., Hilborn, R., Defeo, O., 2011. Leadership, social capital and incentives promote successful fisheries. Nature 470, 3869. doi:10.1038/nature09689

Hanneman, R.A., Riddle, M., 2005. Introduction to social network methods. Riverside, CA: University of California, Riverside (published in digital form at http://faculty.ucr.edu/ hanneman).

Hartley, T.W., 2010. Fishery management as a governance network: Examples from the Gulf of Maine and the potential for communication network analysis research in fisheries. Mar. Policy 34, 1060-1067. doi:10.1016/j.marpol.2010.03.005

Heileman, S., 2011. CLME Project: Reef and Pelagic Ecosystems Transboundary Diagnostic Analysis (TDA). Caribbean Large Marine Ecosystem and Adjacent Areas (CLME) Project, Cartagena, Colombia.

Hoegh-Guldberg, O., Mumby, P.J., Hooten, A.J., Steneck, R.S., Greenfield, P., Gomez, E., Harvell, C.D., Sale, P.F., Edwards, A.J., Caldeira, K., Knowlton, N., Eakin, C.M., Iglesias-Prieto, R., Muthiga, N., Bradbury, R.H., Dubi, A., Hatziolos, M.E., 2007. Coral Reefs Under Rapid Climate Change and Ocean Acidification. Science. 318, 1737-42. doi:10.1126/science.1152509

Hønneland, G., 2000. Compliance in the Barents Sea fisheries. How fishermen account for conformity with rules. Mar. policy 24, 1119.

HRI, 2014. 2014 Eco-Audit of the Mesoamerican Reef Countries: Belize Results. Healthy Reefs Initiative.

Hughes, T.P., Graham, N.A.J., Jackson, J.B.C., Mumby, P.J., Steneck, R.S., 2010. Rising to the challenge of sustaining coral reef resilience. Trends Ecol. Evol. 25, 633-42. doi:10.1016/j.tree.2010.07.011

Husson, F., Josse, J., Le, S., Mazet, J., 2007. FactoMineR: Factor Analysis and Data Mining with R. R package version 1.04, URL http://CRAN.R-project.org/package=FactoMineR.

Imperial, M., Yandle, T., 2005. Taking Institutions Seriously: Using the IAD Framework to Analyze Fisheries Policy. Soc. Nat. Resour. 18, 493-509. doi:10.1080/08941920590947922

Jentoft, S., 2000. Legitimacy and disappointment in fisheries management. Mar. Policy 24, 53-60. doi:10.1016/S0308$597 X(99) 00009-3$

Jentoft, S., 2007. Limits of governability: Institutional implications for fisheries and coastal governance. Mar. Policy 31, 360-370. doi:10.1016/j.marpol.2006.11.003

Jentoft, S., McCay, B.J., Wilson, D.C., 1998. Social theory and fisheries co-management. Mar. Policy 22, 423-436. doi:10.1016/S0308597X(97)00040-7

Jentoft, S., van Son, T.C., Bjørkan, M., 2007. Marine Protected Areas: A Governance System Analysis. Hum. Ecol. 35, 611-622. doi:10.1007/s10745-007-9125-6

Josse, J., Chavent, M., Liquet, B., Husson, F., 2012. Handling Missing Values with Regularized Iterative Multiple Correspondence Analysis. J. Classif. 29, 91-116. doi:10.1007/s00357-012-9097-0 
Kaufman, L., Rousseeuw, P.J., 2005. Finding Groups in Data: An Introduction to Cluster Analysis (Wiley Series in Probability and Statistics). Wiley-Interscience.

Kaufmann, D., Kraay, A., Mastruzzi, M., 2010. The Worldwide Governance Indicators: Methodology and Analytical Issues. Policy Research Working Paper 5430, The World Bank.

Kaufmann, D., Kraay, A., Zoido-Lobatón, P., 2000. Governance Matters From Measurement to Action. Finance Dev. 10-13.

Khan, J., Alleyne, S., 1996. Environmental policy and management in Barbados. Int. J. Public Sect. Manag. 9, $25-35$. doi:10.1108/09513559610109439

Kline, P., 1999. The Handbook of Psychological Testing, 2nd ed. Routledge, New York, USA.

Kooiman, J., Bavinck, M., Jentoft, S., Pullin, R., 2005. Fish for Life: Interactive Governance for Fisheries. Amsterdam University Press, Amsterdam.

Korda, R.C., Hills, J.M., Gray, T.S., 2008. Fishery decline in Utila: Disentangling the web of governance. Mar. Policy 32, $968-979$. doi:10.1016/j.marpol.2008.02.009

Lê, S., Josse, J., Husson, F., 2008. FactoMineR: an R package for multivariate analysis. J. Stat. Softw. 25, 1-18.

Lebel, L., Anderies, J.M., Campbell, B., Folke, C., Hatfield-Dodds, S., Hughes, T.P., Wilson, J., 2006. Governance and the capacity to manage resilience in regional social-ecological systems. Ecol. Soc. 11, 19.

Lockwood, M., 2010. Good governance for terrestrial protected areas: A framework, principles and performance outcomes. J. Environ. Manage. 91, 754-66. doi:10.1016/j.jenvman.2009.10.005

Lockwood, M., Davidson, J., Hockings, M., Haward, M., Kriwoken, L., 2012. Marine biodiversity conservation governance and management: Regime requirements for global environmental change. Ocean Coast. Manag. 69, 160-172. doi:10.1016/j.ocecoaman.2012.07.015 Mackinson, S., Wilson, D.C., Galiay, P., Deas, B., 2011. Engaging stakeholders in fisheries and marine research. Mar. Policy 35, 1824. doi:10.1016/j.marpol.2010.07.003

Maechler, M., Rousseeuw, P., Struyf, A., Hubert, M., Hornik, K., 2013. cluster: Cluster Analysis Basics and Extensions. R package version 1.14.4.

Mahon, R., Bavinck, M., Roy, R.N., 2005. Governance in Action, in: Kooiman, J., Bavinck, M., Jentoft, S., Pullin, R. (Eds.), Fish for Life: Interactive Governance for Fisheries2. Amsterdam University Press, Amsterdam, pp. 353-376.

Mahon, R., Fanning, L., McConney, P., 2009. A governance perspective on the large marine ecosystem approach. Mar. Policy 33, 317-321. doi:10.1016/j.marpol.2008.07.013

Mahon, R., Fanning, L., McConney, P., 2014. Assessing and facilitating emerging regional ocean governance arrangements in the Wider Caribbean Region. Ocean Yearb. 28, 631-671. doi:10.1163/9789004270589

McClanahan, T.R., Davies, J., Maina, J., 2005. Factors influencing resource users and managers' perceptions towards marine protected area management in Kenya. Environ. Conserv. 32, 42-49. doi:10.1017/S0376892904001791

McClanahan, T.R., Hicks, C.C., Darling, E.S., 2008. Malthusian overfishing and efforts to overcome it on Kenyan coral reefs. Ecol. Appl. 18, 1516-29.

McConney, P., Mahon, R., Pomeroy, R., 2007. Challenges Facing Coastal Resource Co-Management in the Caribbean, in: Armitage, D.R., Berkes, F., Doubleday, N.C. (Eds.), Adaptive Co-Management: Collaboration, Learning and Multi-Level Governance. UBC Press, Vancouver, BC, pp. 105-124.

Moberg, F., Rönnbäck, P., 2003. Ecosystem services of the tropical seascape: interactions, substitutions and restoration. Ocean Coast. Manag. 46, 27-46. doi:10.1016/S0964-5691(02)00119-9

Mora, C., 2008. A clear human footprint in the coral reefs of the Caribbean. Proc. Biol. Sci. 275, 767-73. doi:10.1098/rspb.2007.1472

Mora, C., Myers, R.A., Coll, M., Libralato, S., Pitcher, T.J., Sumaila, R.U., Zeller, D., Watson, R., Gaston, K.J., Worm, B., 2009. Management effectiveness of the world's marine fisheries. PLoS Biol. 7, e1000131. doi:10.1371/journal.pbio.1000131

Mumby, P.J., Steneck, R.S., 2008. Coral reef management and conservation in light of rapidly evolving ecological paradigms. Trends Ecol. Evol. 23, 555-63. doi:10.1016/j.tree.2008.06.011

Ostrom, E., 1990. Governing the Commons: The Evolution of Institutions for Collective Action. Cambridge University Press, Cambridge, UK.

Ostrom, E., 2007. A diagnostic approach for going beyond panaceas. Proc. Natl. Acad. Sci. U. S. A. 104, 15181-7. doi:10.1073/pnas.0702288104

Ostrom, E., 2009. A general framework for analyzing sustainability of social-ecological systems. Science 325, 419-22. doi:10.1126/science.1172133

Ostrom, E., 2010. Beyond markets and states: polycentric governance of complex economic systems. Am. Econ. Rev. 100, $641-672$.

Persha, L., Agrawal, A., Chhatre, A., 2011. Social and ecological synergy: local rulemaking, forest livelihoods, and biodiversity conservation. Science. 331, 1606-8. doi:10.1126/science.1199343

Pita, C., Pierce, G.J., Theodossiou, I., 2010. Stakeholders' participation in the fisheries management decision-making process: Fishers' perceptions of participation. Mar. Policy 34, 1093-1102. doi:10.1016/j.marpol.2010.03.009 
Plummer, R., Armitage, D., 2007. A resilience-based framework for evaluating adaptive co-management: Linking ecology, economics and society in a complex world. Ecol. Econ. 61, 62-74. doi:10.1016/j.ecolecon.2006.09.025

Plummer, R., Crona, B., Armitage, D.R., Olsson, P., Tengö, M., Yudina, O., 2012. Adaptive Comanagement: a Systematic Review and Analysis. Ecol. Soc. 17, art11. doi:10.5751/ES-04952-170311

Pollnac, R., Christie, P., Cinner, J.E., Dalton, T., Daw, T.M., Forrester, G.E., Graham, N.A.J., McClanahan, T.R., 2010. Marine reserves as linked social-ecological systems. Proc. Natl. Acad. Sci. U. S. A. 107, 18262-5. doi:10.1073/pnas.0908266107

Pomeroy, R., McConney, P., Mahon, R., 2004. Comparative analysis of coastal resource co-management in the Caribbean. Ocean Coast. Manag. 47, 429-447. doi:10.1016/j.ocecoaman.2004.09.005

Pomeroy, R.S., 2007. Conditions for Successful Fisheries and Coastal Resources Co-Management: Lessons Learned in Asia, Africa, and the Wider Caribbean, in: Armitage, D.R., Berkes, F., Doubleday, N.C. (Eds.), Adaptive Co-Management: Collaboration, Learning and Multi-Level Governance. UBC Press, Vancouver, BC, pp. 172-190.

Pomeroy, R.S., Douvere, F., 2008. The engagement of stakeholders in the marine spatial planning process. Mar. Policy $32,816-822$. doi:10.1016/j.marpol.2008.03.017

Pomeroy, R.S., Katon, B.M., Harkes, I., 2001. Conditions affecting the success of fisheries co-management: Lessons from Asia. Mar. Policy 25, 197-208. doi:10.1016/S0308-597X(01)00010-0

R Core Team, 2013. R: A language and environment for statistical computing. R Foundation for Statistical Computing, Vienna, Austria.

Raakjær Nielsen, J., 2003. An analytical framework for studying: compliance and legitimacy in fisheries management. Mar. Policy 27, 425-432. doi:10.1016/S0308-597X(03)00022-8

Raakjær Nielsen, J., Mathiesen, C., 2003. Important factors influencing rule compliance in fisheries lessons from Denmark. Mar. Policy 27, 409-416. doi:10.1016/S0308-597X(03)00024-1

Rauschmayer, F., Berghöfer, A., Omann, I., Zikos, D., 2009. Examining processes or/and outcomes? Evaluation concepts in European governance of natural resources. Environ. Policy Gov. 19, 159-173. doi:10.1002/eet.506

Reynolds, a. P., Richards, G., Iglesia, B., Rayward-Smith, V.J., 2006. Clustering Rules: A Comparison of Partitioning and Hierarchical Clustering Algorithms. J. Math. Model. Algorithms 5, 475-504. doi:10.1007/s10852-005-9022-1

Ritchie, H., Ellis, G., 2010. "A system that works for the sea”? Exploring Stakeholder Engagement in Marine Spatial Planning. J. Environ. Plan. Manag. 53, 701-723. doi:10.1080/09640568.2010.488100

Salas, S., Chuenpagdee, R., Seijo, J., Charles, A., 2007. Challenges in the assessment and management of small-scale fisheries in Latin America and the Caribbean. Fish. Res. 87, 5-16. doi:10.1016/j.fishres.2007.06.015

Sandstrom, A., Rova, C., 2010. Adaptive Co-management Networks: a Comparative Analysis of Two Fishery Conservation Areas in Sweden. Ecol. Soc.

Spalding, M., Bunting, G., 2004. A Guide to the Coral Reefs of the Caribbean. University of California Press.

Schwarz, A.-M., Béné, C., Bennett, G., Boso, D., Hilly, Z., Paul, C., Posala, R., Sibiti, S., Andrew, N.L., 2011. Vulnerability and resilience of remote rural communities to shocks and global changes: Empirical analysis from Solomon Islands. Glob. Environ. Chang. 21, 1128-1140. doi:10.1016/j.gloenvcha.2011.04.011

UNEP, 2006. Marine and coastal ecosystems and human well- being: A synthesis report based on the findings of the Millennium Ecosystem Assessment. UNEP.

Warner, T.E., Pomeroy, R.S., 2012. Paths of Influence: The Direct and Indirect Determinants of Marine Managed Area Success. Coast. Manag. 40, 250-267. doi:10.1080/08920753.2012.677630 